(Jpn. J. Hosp. Pharm.

$\left(\begin{array}{lll}24(1) & 55-62 & (1998)\end{array}\right)$

\title{
内服薬の区別と注意書きの識別に関する実態調査
}

\author{
朝倉俊成 $\dagger^{*} \dagger^{1}$, 野崎征支郎 $\dagger^{1}$, 清野弘明 $\dagger^{2}$, 阿部隆三 $\dagger^{3}$
}

太田西八内病院薬鼡部 $\dagger^{1}$, 同糖尿病センター内科 $\dagger^{2}$

\section{Survey on Identifying Medicines and Understanding of Attention Instructions}

\author{
TOSHINARI ASAKURA ${ }^{*} \dagger^{1}$, SEISHIRO NOZAKI $\dagger^{1}$, HIROAKI SEINO $\dagger^{2}$ and RYUZO ABE $\dagger^{2}$ \\ Department of Pharmacy $\dagger^{+1}$, Internal Medicine Diabetic Center $\dagger^{2}$, Ohta Nishinouchi Hospital
}

\author{
$\left(\begin{array}{ll}\text { Received May 12, } 1997 \\ \text { Accepted September 22, } 1997\end{array}\right)$
}

Due to the increasing number of aging patients and the number of medicines, problems continually a rise in regard to distinguishing medicines.

A survey on how patients distinguish medicine and how well they understand the directions was conducted with 51 patients taking lectures at the diabetes section of our hospital (average age $55.9+12.8$, mean \pm SD). A survey was conducted by inquiry. Patient average eyesight was $0.8 \pm 0.4$ (right eye) and $0.8 \pm 0.5$ (left eye).

Whether they understood an enlarged illustration of how to remove a pill from a PTP sheet, $76.5 \%$ answered "understandable" while only $41.2 \%$ could not recognize the full-size illustration. In response to a question on the ease of reading the directions on the back of the PTP packaged tablet, $40.5 \%$ answered "easy to read". The size of the letters they recognized as "easy to read"was 13 points or larger.

This survey revealed that almost half of the patients could not recognize medical information despite improvements of PTP packaging. Supplementary explanations and confirmations are thus necessary when giving patients dose instructions.

Key words — PTP (press through pack), dose instruction, distinguish, eyesight, medical information

\section{緒言}

近年，患者の高齢化や慢性疾患の増加にともな い医薬品の多剤傾向が問題になってきている。一 方で，医薬品の製剤技術の進歩により，薬理学的 に特徴ある剤形や服用（使用）方法の発展がみら れるようになってきた。

$\dagger^{1,2}$ 福島県郡山市西ノ内 2-5-20;2-5-20, Nishinouchi, Koriyama, Fukushima, 963-8022 Japan
特に, 糖尿病領域に使用される医薬品（エパル レスタット, スルホニル尿素剤， $\alpha$-グルコシダー ゼ阻害剤など）に代表されるように，食後以外に 食前や食直前などの服用時点が薬効に大きく反映 する事例が増えてきた。

また, PTP (press through pack) 包装の誤飲が 多い1)ことから, PTPの誤飲対策が行われるよう になってきた ${ }^{2,3}$.しかし，実際に患者は自分で 服用している医薬品について識別でき, かつ包装 
に記載されている注意事項について認識できない と，医薬品を適正に使用する上で十分な環境整備 であるとは言えない。

そこで著者らは，内服薬に関しての識別と包装 に記載してある注意書きの認識に関する実態を調 查したのでここに報告する.

\section{方法}

教育入院を目的とした当院糖尿病入院患者51名 (M/F：25/26名，年齢 55.9土12.8 歳：M土SD） を対象とし，患者が糖尿病教室受講時に約10分程 度で Fig. 1-1，1-2のアンケート（A 3 判 2枚） に答えてもらった，さらに，Fig. 2のような文字 の大きさを実際に見てもらい，「見やすい文字と しての大きさについて最小許容ポイント」につい ても答えてもらった。なお，調査期間は，1996年 12月〜1997年 1月とした.

また，質問項目によっては対象患者を左右の視 力で良い方の值を基に，視力が1.0以上（I 群）， 0.5 0.9 (II 群)，0.4以下（四群）として解析し た.

\section{結果}

はじめに各群の患者背景を示し, 結果はアン ケート項目に添って報告する。

1 ）群別の患者背景

各群別の患者人数，平均年齢および平均視力 は, I 群が25名 $(\mathrm{M} / \mathrm{F}=13 / 12$ 名, 52.3土12.5歳) で右の視力が $1.1 \pm 0.3$, 左が $1.2 \pm 0.2$ であり， II 群が16名（M/F=9/7名，60.1土12.1歳）で右 の視力が $0.6 \pm 0.1$, 左が $0.5 \pm 0.2$, III群が 10 名 $(\mathrm{M} / \mathrm{F}=3 / 7$ 名, 58.1 13.1 歳) で視力は左右 とも0.2土0.1であった。また患者全体の視力は， 右が $0.8 \pm 0.4$ で左が $0.8 \pm 0.5$ であった.

2 ）新聞の文字が見えるか.

「新聞の文字が見えるか」は，I群が92.0\%， II 群が $81.3 \%$ ，四群が $30.0 \%$ ，全体で $76.5 \%$ 見 えると答えていた。

3 ) 現在飲んでいる薬の数
対象患者全体の「現在飲んでいる薬の数」は, $\lceil 1 ３$ 錠」が35.3\%，「4〜6錠」が $23.5 \%$ ， $\lceil 7 \sim 10$ 錠」が7.8\%，「10錠以上」が5.9\%,「飲ん でいない」が21.6\%,「わからない」が5.9\%であ つた。

4 ）自分が飲んでいる薬が複数あった場合，区 別して飲むべきだと意識しているか.

対象患者全体の結果は, 「意識している」が $72.0 \%$ ，「意識していない」が28.0\%であった.

5 ) 自分の薬は他の薬と区別できるか.

対象患者全体の結果は,「区別できる」が71.4\%， 「区別できない」が28.6\%であった。

6 ）薬の区別や確認に際し，何に注意している か (複数解答あり).

対象患者全体の結果を Fig. 3 に示した.

7 ）今まで, 内服薬の区別で困ったこと.

困ったことがあると答えた割合は，I群が $8.0 \%$ ，II群 が $12.5 \%$ ，四群 が $30.0 \%$ ，全体で 13.7\%であった。 その理由として「同じような色 と包装がある」や「種類が多く1２度の説明で はわからない」があった。

8 )「PTP 裏面の取り出し図柄」の意味とその 内容の理解度。

日本製薬団体連合会の「PTP 裏面の取り出し図 柄」を見やすいように $40 \times 25 \mathrm{~mm}$ に拡大し(Fig. 1 1 ），その意味を尋ねた。対象患者全体で，「意味

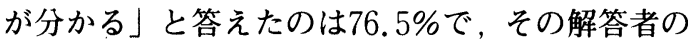
82.1\%が正解であった。つまり，正しく理解して いた患者は全体の $62.7 \%$ であった。

9 ）今までに，薬を包装から出さないで飲もう とした（飲んでしまった）ことがあるか.

対象患者全体で「飲もうとしたことがある」は 7.8\%（62.8土9.9歳）で，「飲んでしまったこと がある」は3.9\% (68.0土8.5歳)であった.

10）包装の印や文字に注意しているか.

対象患者全体の78.4\%が「注意して見ることが

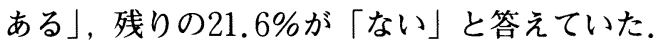

11）「おしだす」という文字は見やすいか. ここでは，実際にボルタレン錠（ノバルティス 


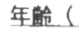

$$
\text { 才) 性別(男·女) }
$$

1：あなたの視力はいくつですか？（眼鏡を使用している 方は眼鏡使用時の視力を記入してください)

$$
\text { ii ( ) ti: ( ) }
$$

2 : 普段、新闌の文字は見えますか?

$$
\text { (1)はい (2)いいえ }
$$

3：現在、敛んでいる菜は何個ですか？
(1) $1 \sim 3$ 佔
(2) $4 \sim 6$ 佔、
(3)7 10)做、
(4)1010周以 1:
(5)沾んでいない、(西わからない

4：自分の钦んている柔が掼数あった場合：区別して飲む

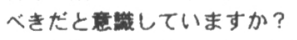

(1)离醷している. (2)意墥していない

5：自分の钦んでいる承は他の莯と区別できますか？
(1)できる、
(2)できない

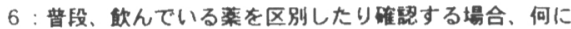

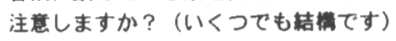

(1)錠剂・カフ十セル剂の大ささ、(2) 浆の形、

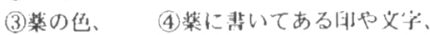

(5)包裴の色やデザイン。

(6)创装に書いてある印や文子、

(7)その他（
7 : 今まで、内服薬の区別で困ったことはありませんか? ある方は、なぜ困ったかという理由を箸単に異いてく ださい。

(1)ある

(2)ない

8：この図を見て、意味が分かりますか？分かる方は䑺 单にその内容を震いてください。

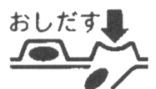

(1)分かる(

(2)分からない

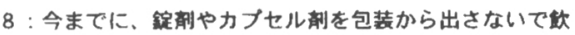
もうとしたり、钦んでしまったことはありますか？
(1)飲もうとしたことか
ある
ない
(2)飲んだことが
ある ない

9 : 普段、薬の包装に書いてある印や文字を注意して見る ことはありますか?

(1)ある

(2)ない

Fig. $1-1$

10 : 下の楽の包装で、「おしだす」という文字は見やすい ですか？見にくいと答えた方はその理由を害いてく ださ。

$$
p r a
$$

\section{(1)見やすい}

(2)胃にくい(

$11:$ この来の文字は見やすいですか？

(1)「传前に服朋」という文'

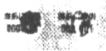

(1)兄けすい，(2)見にくい

(2) 传南前に服用」という文け

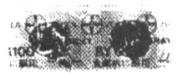

(1)心やすい、(2)少にくい

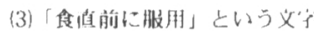

(1)岂やすい、(2)見にくい
12：あなたは、薬物滰法についての情啹をどこから得てい

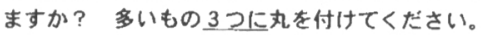

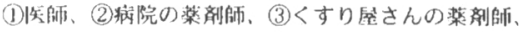

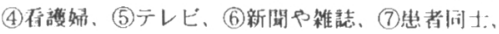
(8)家族や親墄、(9)友人や近所の人 (10)その他（）

$13:$ 薬のことで本当に困ったら、どうしますか？ 2つ選んでください。

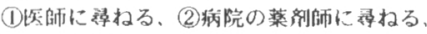

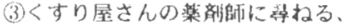

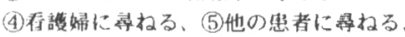
(6)白分で本などで調べる、(7)家族や親战に開く、 (8)友人や近所の人に開く、(9)その他（

14:その他、菜の区別に閑して、気がついたこと、要望な どありましたらお害きください。

こ協力有鏶うこさいました。 太田西/内病院霖郕部 


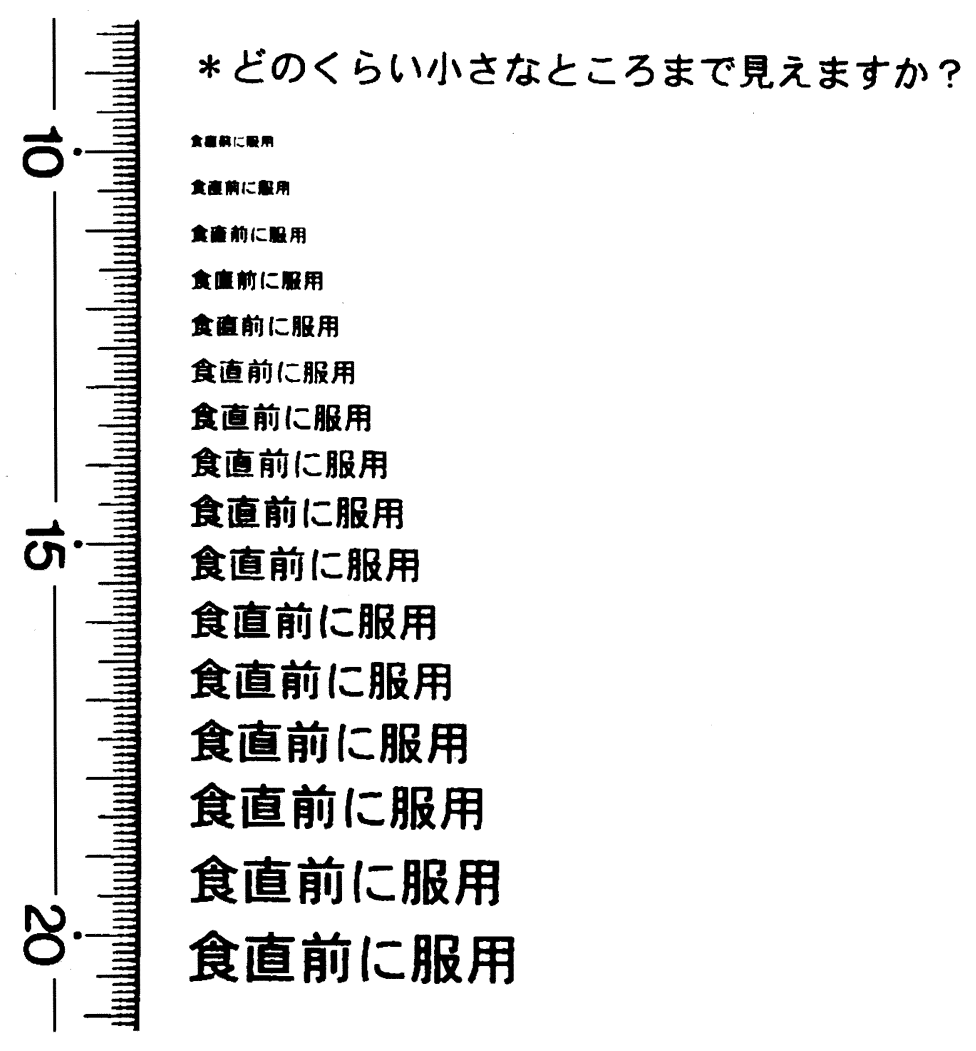

Fig. 2. どのくらい小さなところまで見えますか？

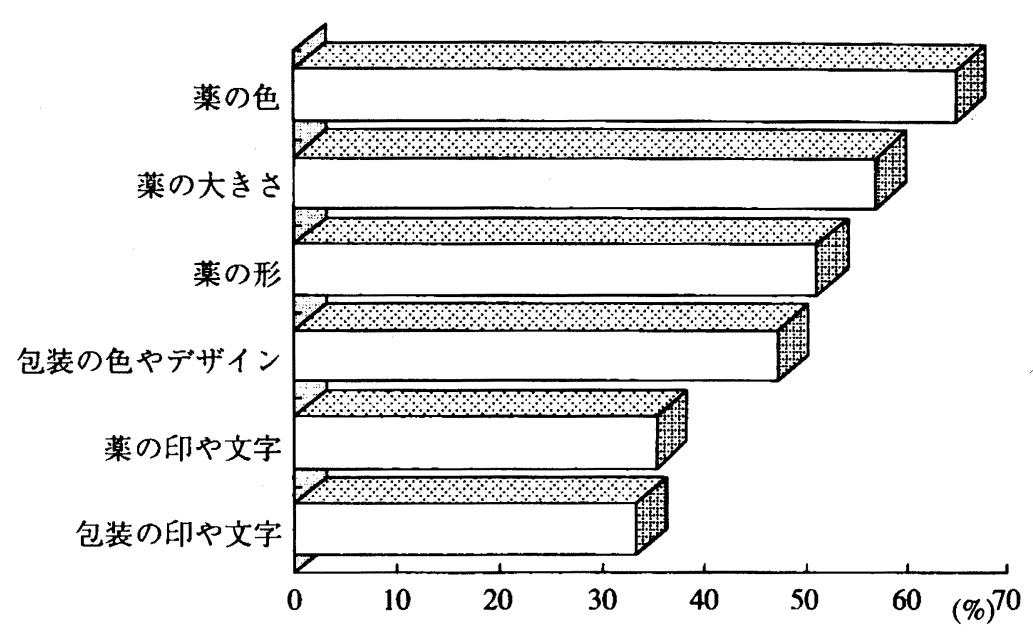

Fig. 3. 薬の区別や確認する場合の注意点 
ファーマ）の PTP 裏面にある日本製薬団体連合 会の「PTP 裏面の取り出し図柄」にある「おしだ す（6ポイント）」について見やすさを答えても らった.

結果は, 各群 Fig. 4 のようになった.

また，「見にくい」と答えた理由の $93.3 \%$ は 「小さくて見にくい」であった.

12）注意書きの文字の見やすさ

Fig. 1-2のように，アンケート中にキネダッ ク(小野薬品工業), グルコバイ $100 \mathrm{mg}$ (バイエル 薬品), ベイスン $0.2 \mathrm{mg}$ (武田薬品工業) を添付 し，実際の「食前に服用」や「食直前に服用」の 注意書きの見やすさを尋ねた。結果は Fig. 5

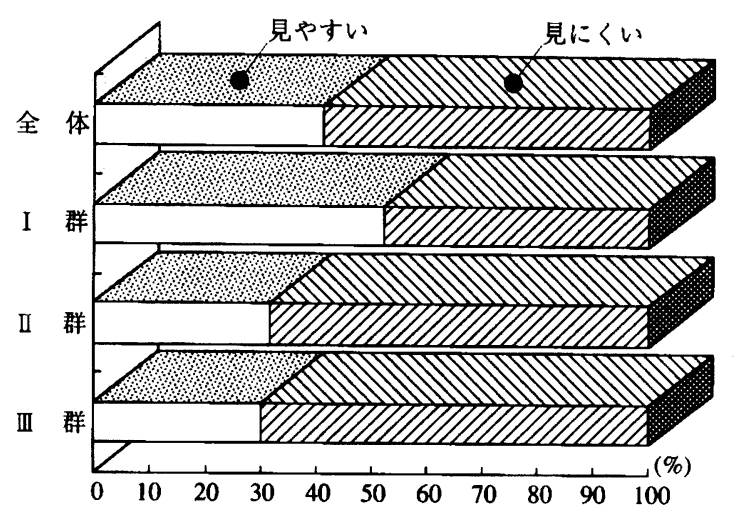

Fig. 4.「おしだす」の見やすさ

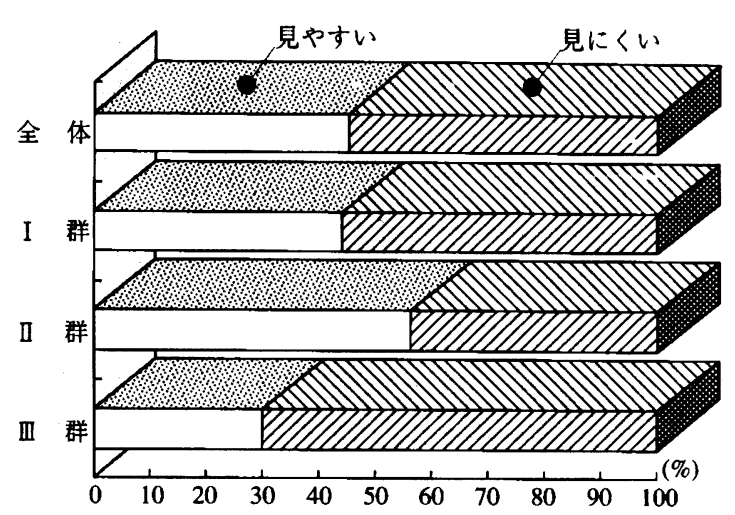

Fig. 6.「食直前に服用」(グルコバイ) の見やすさ
7のとおりであった。なお，各薬剤はFig. 8 の とおりで, 注意書きに関する文字の大きさ等は Table 1 に示した。

13）薬物療法についての情報をどこから得てい るか ( 3 つ選択).

対象患者全体の結果は, Fig. 9のとおりであっ た.

14）薬のことで困ったらどうするか（2つ選 択).

対象患者全体の結果は, Fig. 10のとおりであっ た。

15）見やすい文字の大きさ

結果はFig.11のようになった。

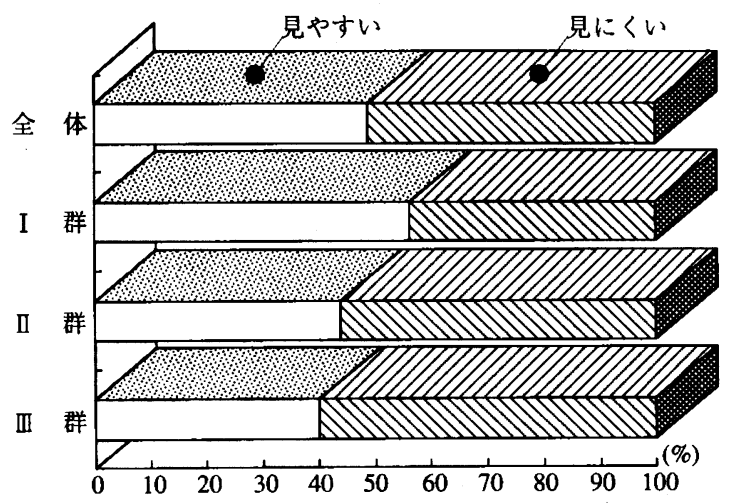

Fig. 5.「食前に服用」(キネダック) の見やすさ

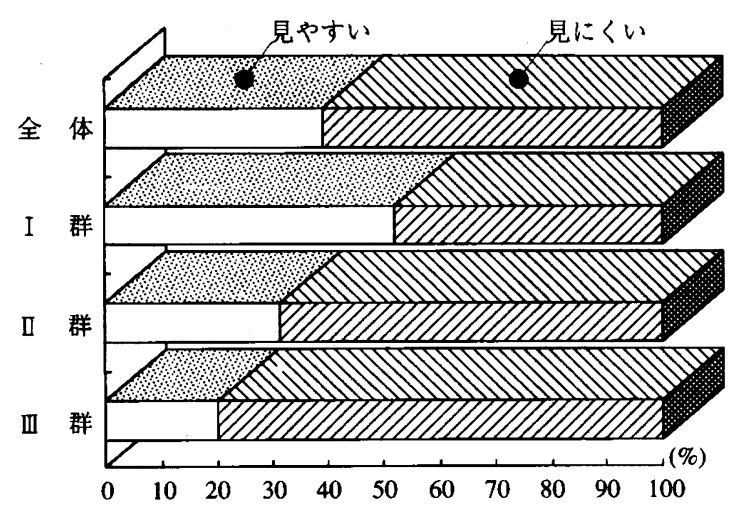

Fig. 7.「食直前に服用」(ベイスン) の見やすさ 
Table 1，各薬品の注意書きの字体と大きさ

\begin{tabular}{|c|c|c|c|c|c|}
\hline 医薬品名 & 規格 & メーカー名 & 字 & 大きさ & 実測値(1文字) \\
\hline キネダック & - & 小野薬品 & ナールD & 9Q(6ポイント相当 & 約 $2.25 \times 2.25 \mathrm{~mm}$ \\
\hline グルコバイ & $100 \mathrm{mg}$ & バイエル薬品 & モリサワ太ゴシック(B101) & ) $12 \mathrm{Q}$ (8ポイント相当) & 約 $3.00 \times 3.00 \mathrm{~mm}$ \\
\hline ベイスン & $0.2 \mathrm{mg}$ & 武田薬品 & ゴナD写研 & 10Q(7ポイント相当) & )約 $2.50 \times 2.50 \mathrm{~mm}$ \\
\hline
\end{tabular}

(いずれもメーカー問い合わせより)

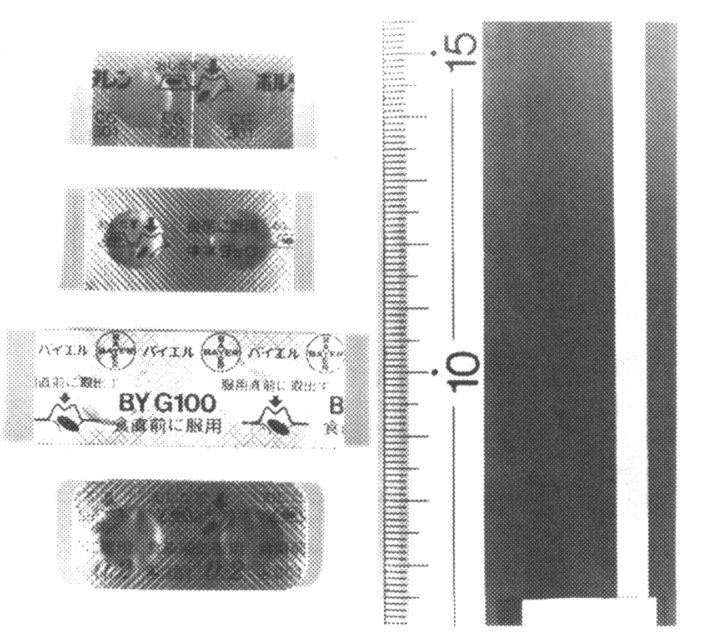

Fig. 8．アンケートに用いた実薬（包装裏面）

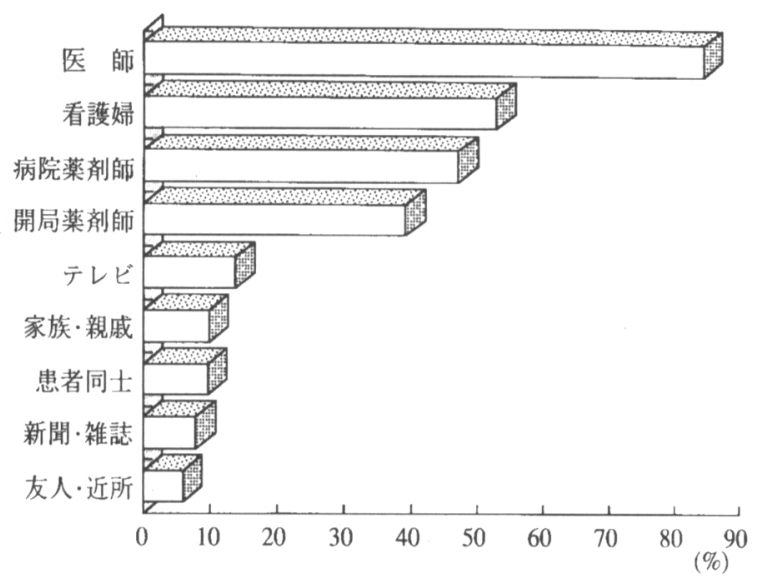

Fig. 9. 薬物療法の情報をどこから得るか

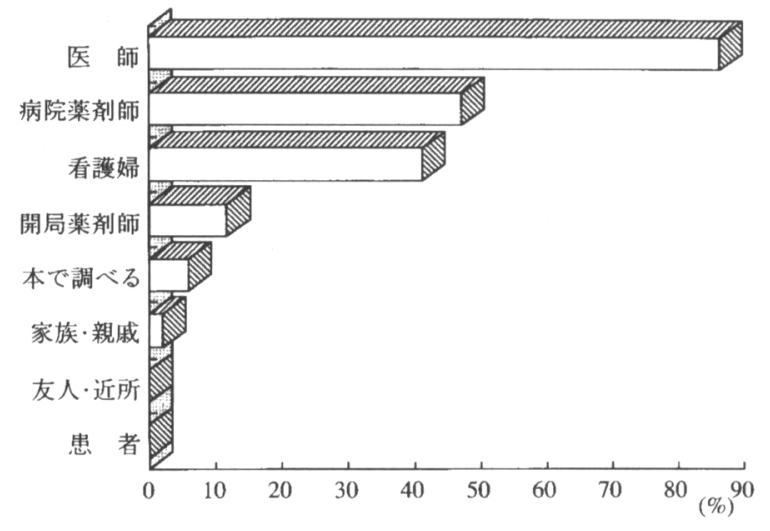

Fig.10. 薬のことで困ったら誰に尋ねるか

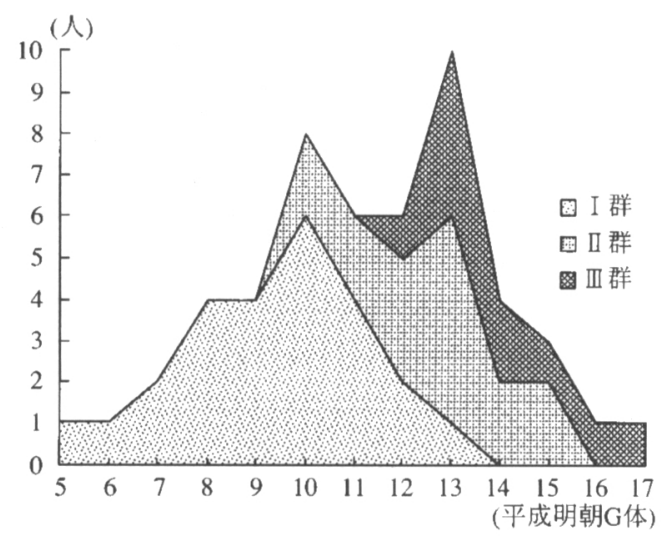

Fig. 11. 見やすいポイント (累積值) 


\section{考察}

「医薬品の適正使用」は，医薬品の薬学的管理 の他に患者が正しく服用することも重要な事項で あることは言うまでもない。一般に，患者への医 薬品使用に関する指示 (指導) や注意事項などの 提供は，口頭や文書などにて行われる。したがっ て，その伝え手である医療側は，患者の理解度に 合わせて伝え方や表現などを十分に考慮しながら 進めなければならない。

しかしその前に，患者指向という視点で服薬指 導の在り方という基本的な点を確認しておくこと が重要と考える．著者は，以前服薬指導用語の理 解度を患者および中学生で調査したが，用語の理 解度は両者とも決して高いものとは言えなかっ $た^{4)}$ ，今回の調查では，近年問題となっている PTP シートの誤飲を防止するための図柄や，服薬 時点の注意を促す語句の印字が，「患者へ正しく 情報を伝える」という目的に真に沿って成り立っ ているかということを確認すること，さらに，患 者は自分の服用している内服薬の識別に対してど の程度関心があるのかという実態を知るために行 った.

今回，糖尿病教室受講患者を対象としたのは， 糖尿病患者は薬物療法について関心が高いにもか かわらず糖尿病性網膜症などによる視力障害を有 する率が高いことから，本調查に最も適している と考えたからである。

\section{1 ）視力と識別}

本調査では，「識別」ができるかという観点か ら, 視力別に 3 群に分けて解析した.

結果を見ると，薬の区別や確認は，薬の「色」 や「大きさ」，「形」によって行われることが多い ことがわかった．また，実際に区別で困ったこと がある割合は, 視力が 0.4 以下である III群が他の 群よりも多く，視力が識別に大きく影響すること が確認された。

一般に, 新聞の文字が見える視力は 0.5 以上と いう見解 ${ }^{5)} も$ あり, 本調査でもこの傾向が示唆
された。

2 ）薬の区別への意識

患者は医薬品を区別して服用しているかとい う，いわゆる「区別に対する意識」についての結 果をみると, 全体の $72.0 \%$ が意識しているとして おり，自分の薬を他の薬と区別できると答えたの も71.4\%と高い数值てあった。

\section{3 ) 包装の図柄や印字の理解度}

「PTP 裏面の取り出し図柄」は, 日本製薬団体 連合会が PTP 誤飲を防止する目的で表示される ことになったが，その図柄（拡大図）の理解は全 体の $62.7 \%$ と高かった。しかし，そこにある「お しだす」の実際の文字が見やすいと答えたのは全 体の $41.2 \%$ あ゙り, 実物大での見やすさの割合は 低かった。

さらに，服用時点の注意書きで「見やすい」と したのは, キネダック, グルコバイ , ベイスンに おいていずれも 40～50\%であり，視力の低下にし たがって「見やすい」割合は低くなる傾向が見い 出された。

また，それぞれの文字の大きさは Table 1 に示 すとおりであるが，見やすい文字の大きさの調査

（Fig.11）では13ポイント以上が必要という結果 が得られた。よって，PTP 裏面に記載する文字の 大きさも，このことを考慮にいれて改良すべきと 考える.しかし, PTP 裏面のスペースの問題から 小さくせざるを得ない現状も否定できない，た だ，錠剤の大きさはともかく，PTPをある程度大 きくすることは情報提供の観点から行えるポイン トと考える.

今回の調査では，文字の大きさでの検討を中心 に進めたが, 文字と背景の色調の組み合わせによ る識別性も影響があるとの報告もあるので6.7)，今 後これらも加味して工夫していかなければならな い.

4 ）薬物療法についての情報の入手

患者の薬物療法についての情報に関しては，入 手先が医師・看護婦・病院薬剤師の順に多く, 薬 のことで困ったときは医師・病院薬剤師・看護婦 
の順で尋ねるという回答であった，開局薬鼡師へ の回答は少なかったのは, 現在（1997年 5 月）の 当院における院外処方嘎発行の割合が約 $25 \%$ あ り，まだ開局薬剽師と接触を持っていない患者も 多いことを反映しているものと思われる.

しかし，マスコミをはじめ社会的に薬に関する 情報が氾濫している今日，薬物療法に関する情報 の入手や相談相手に医療スタッフが選ばれたこと は，重要なことであると考える。

\section{5 ) 今後の対応}

本調査から , 患者の内服薬の区別や注意書きの 認識について, 文字や図柄の大きさが小さいとい う点から約半数しか認識できていないという実態 が確認された。たとえ製薬メーカーが注意書きを 明記したとしても，患者の薬の区別に対する「意 識」は 7 割以上あるにもかかわらず，それを患者 が読めなければ本来の意味を発揮することはな (?.

したがって, 注意書きは十分に判読できる文字 の大きさや書体, さらには色調の検討も行う必要 がある，本調査結果では，文字の大きさは13ポイ ント以上が良いとされたことから，PTPへ可能な 限りそれに近付けた方向へと改良していただける よう製薬メーカーに要望したい.

また, 服薬指導を行う際, 薬剤師は患者が理解
していない点を見い出し，患者個々に補足してい くことも重要なことである。その点で, 薬の区別 や注意書きの情報提供もあらゆる方法で患者の理 解度を確認し, 繰り返し説明することも大切であ ると考える。

情報提供の手段は, 適確に情報を伝達するとい うことを基本に構築されなければならない。しか し，それを実践する場合，使用者（提供者）は単 に提供するということではなく，患者個々にあわ せて補足説明するということも重要になってく る。したがって，現状のシステムをこのような視 点で再検討して行くことも，臨床現場で業務に携 わる薬剤師の大きな役目と考える。

\section{引用文献}

1) 岩田重信, 小林由充子, 高須昭彦, 内藤健晴, 森茂樹, 井畑克朗, 浦野誠, 岩田義弘, 横山尚 樹，日気食会報，46 (5), 406-418 (1995).

2) 日本製薬団体連合会, 日薬連発第335号 (1996).

3) 日本製薬団体連合会, 日薬連発第240号 (1996).

4) 朝倉俊成, 野崎征支郎, 病院薬学, 22 (5), 497502 (1996).

5）繁田幸男監修, “糖尿病検査マニュアル”,南江 堂 (東京) , 1993,p. 96.

6) 丹野慶紀,PHARM TECH JAPAN, 1 (12), 12141220 (1985).

7) 杉原正春, 日高正人, 斎藤明美, 病院薬学, 12 (4), 322-328 (1986). 